Mehdi Farsi, Massimo Filippini

An empirical analysis of cost efficiency in non-profit and public nursing homes

Quaderno N. 03-06

Decanato della Facoltà di Scienze economiche

Via G. Buffi, $13 \mathrm{CH}-6900$ Lugano 


\title{
AN EMPIRICAL ANALYIS OF COST EFFICIENCY IN NON-PROFIT AND PUBLIC NURSING HOMES*
}

\author{
Mehdi Farsi Massimo Filippini \\ Department of Economics \\ University of Lugano \\ Via Ospedale 13, 6900 Lugano, Switzerland \\ and \\ Center for Energy Policy and Economics \\ Federal Institute of Technology \\ ETH Zentrum, WEC, 8092 Zurich, Switzerland
}

February 2003

\footnotetext{
* We are grateful to Luca Crivelli for his comments and suggestions. We would also like to thank Chiara Gulfi and Ilaria Mosca for their excellent assistance and Giorgio Borradori for his help in understanding the data. This research has been partially financed by Ticino's Dipartimento Sanità e Socialità. We thank this department for their support and also for providing the data. The views expressed in this paper are strictly personal. Responsibility for any remaining errors lies solely with the authors.
} 


\begin{abstract}
This paper examines the issue of cost-efficiency in Switzerland's nursing homes, an issue of concern to policy makers because of the rapid growth of elderly care expenditure and the aging of the population. The fact that nursing homes in Switzerland exist in different institutional forms, private for-profit, government and non-profit status, raises the issue of their relative cost efficiency. A panel data of 17 public and 19 nonprofit nursing homes operating over the 9-year period from 1993 to 2001, in one of the 26 Swiss cantons, Ticino, is studied. Ticino's nursing homes are heavily regulated and monitored by the canton's authorities. However, given that in public firms there are more bureaucratic constraints and agency problems, one can expect a relatively low level of cost-efficiency. In this paper the effect of institutional form on efficiency is studied using a translog stochastic cost-frontier model. Several specifications are used to study the robustness of the results. The results suggest that the institutional form influences the efficiency of the studied nursing homes in that non-profit foundations are likely to be more cost-efficient than the nursing homes operated by government administration. The results also suggest that a great majority of the nursing homes in the sample do not fully benefit from the scale economies. This implies that efficiency gains can be obtained with larger capacities or joint operations.
\end{abstract}

\title{
1. Introduction
}

Switzerland is a federal state composed of 26 cantons and approximately 3,000 municipalities. ${ }^{1}$ The federal state is characterized by a high degree of decentralization in the provision of public services. Article 3 of the Federal Constitution grants large autonomy to individual cantons in the sectors, such as health and social care, which are not directly regulated by the constitution. For instance, individual cantons are independent in the organization and regulation of the provision of long-term care for elderly people. While in most cases the provision of this service is organized at the cantonal level, some cantons such as Ticino considered in this analysis, decentralize the task to "communes" (local

1 Three cantons further divided into semi -cantons. The most populated canton is Zurich with a population of 1.2 million and the smallest one is Appenzell Interrhoden with slightly more than 15,000 inhabitants. 
governments). The autonomy of the cantons creates a strong heterogeneity in the organization and regulation of the nursing home sector in Switzerland.

Generally the long-term care for the elderly is provided by non-profit nursing homes and private for-profit nursing homes. ${ }^{2}$ Non-profit nursing homes can be further distinguishes in private and public nursing homes. From the institutional point of view, private non-profit nursing homes are generally foundations, whereas public nursing homes are so called "Municipalizzate", e.g. firms without an own juridical status integrated directly in the local public administration. However, in few cases, local governments have chosen to create also a foundation to run their own nursing homes. In theses cases, these types of public nursing homes are generally, more independent from the local political and public administration process than nursing homes directly included in the public administration. This mixed economy raises the interesting issue of the effects of different ownership and institutional forms on costs.

A number of recent studies have compared the cost efficiency of non-profit and forprofit hospitals and nursing homes. ${ }^{3}$ However, little empirical analysis has been done in the comparison of cost efficiency between public and private nonprofit nursing homes. In this paper we test the hypothesis that nursing homes operated by private nonprofit are more efficient than those managed by local governments. This hypothesis is based on the conjuncture that the managers in public organizations are faced with more bureaucratic constraints than those in private non-profit foundations. Moreover, compared to government employees, the managers in non-profit organizations have more intrinsic motivations to have a more efficient performance. Finally, as we see later in the paper the agency problems in a public organization are likely to occur in a higher number of levels and with more friction than in non-profit foundations.

For this purpose we estimate a cost function using data from a sample of 36 nonprofit nursing homes (public and private) operating in Ticino, a Swiss canton with a population of approximately 300,000 and an area size of 2,812 square $\mathrm{km}$. Ticino is chosen because the planning of its new nursing homes is on the government's agenda and therefore there is a need to determine the nursing home's optimal capacity and the preferable ownership and organizational form. Moreover, Ticino's nursing homes can be considered as a relatively

\footnotetext{
2 In Switzerland, nursing homes provide social care services as well as health care services to their patients. In fact, the residents' average dependency and their need for medical care have been substantially rising during the last 15 years. Virtually all nursing homes have adapted the training of their staff and their infrastructure to provide health care services to their patients.

3 See for example Vitaliano et al. (1994), Bradford and Mobley (1997) and McKay (1988).
} 
uniform sample regarding the quality of services as well as the financial incentives of their managers. Finally, Ticino's cantonal administration regularly collects data from all the nursing homes operating in the canton and the data collected over the past years allow a panel data analysis. The hypothesis is tested using a two-stage methodology. In the first stage the nursing homes' inefficiency scores are estimated using a cost model specification without controlling for organizational form. The estimated results are analyzed in a second stage to test for a significant difference between the two types. The cost frontier model used in the first stage is based on the random-effects model. Two specifications are used to study the effect of potential biases due to the endogeneity of the quality of care.

The paper is organized as follows. Section 2 presents the organization of the nursing home sector in Canton Ticino. A discussion on efficiency and institutional form is given in section 3. Section 4 discusses the cost model and its econometric specification. Section 5 presents the data, while section 6 illustrates the empirical results. Section 7 concludes the paper.

\section{The organization of the nursing home sector in Ticino}

The nursing home sector in canton Ticino, with 67 homes, represents an important element of the social care sector for elderly people. The most important characteristics of this sector are as follows:

- A variety of institutional forms operate in the market;

- The market is heavily regulated by the state;

- The state provides a large financial support in the form of subsidies. ${ }^{4}$

In Ticino, as well as in other Swiss cantons, there are different institutional forms operating in the nursing home sector, i.e. private for-profit nursing homes, non-profit private institutions and public institutions. Crivelli, Filippini and Lunati (2002) provide a detailed description of different organization types in Switzerland's nursing homes and their distribution across cantons. In all Swiss cantons there is a clear majority of non-profit nursing homes (i.e. public and private non-profit institutions). However, in some cantons there are more public institutions and in others more non-profit private institutions. Among 67 Ticino's nursing homes, 24 are public, 32 are operated by private non-profit foundations, 6 are nonprofit foundations created by municipalities, and 5 are private for-profit. The organizational structure of different nursing homes is discussed in the next section. The for-profit sector 
accounts for about 5 percent of the nursing home beds in Ticino. For-profit nursing homes are not considered in this study. ${ }^{5}$

Ticino's nursing homes are therefore dominated by non-profit and public firms that are strongly regulated and subsidized by the government. Economists generally regard competitive markets as the best way to promote an efficient allocation of resources. However, they recognize that there are circumstances where competitive markets fail to bring about an optimal allocation of resources. Three basic arguments for market failure in the nursing home industry are: (1) the local natural monopoly argument, which is typical of nursing homes in peripheral areas, (2) the lack of comprehensive information on the quality of care for the users of residential services and (3) the merit goods argument. In the latter case the state considers the services provided by nursing homes to be a merit good and therefore it recognizes the need to give them a financial contribution through the general fiscal system and to regulate their tariffs. For these reasons Ticino's government has adopted the following forms of regulation: approval of the daily rates, definition of the minimum necessary infrastructure and staff requirements, control of the supply capacity in terms of beds, and concession of a financial contribution in the form of subsidies to public and non-profit nursing homes.

The regulation of the nursing homes in Ticino has shown at least three consequences:

- The subsidized price of residential care results in a significant increase in demand. The subsidized daily rates give families an incentive to transfer the burden of care of their elderly relatives to the state thus creating an excessive demand.

- To counteract this demand excess, the state controls the supply side by erecting barriers to entry to the market. For instance, in order to get subsidies for operating costs and health insurance reimbursement for medical care, a nursing home has to figure in the nursing home planning of the canton.

- The gap between supply and demand makes the use of a rationing tool necessary. In the case of Ticino this is represented by waiting lists.

\section{Institutional form and efficiency}

Property rights theory has often been used to compare the efficiency of private nonprofit organizations and for-profit firms. Following Alchian (1965) and Demsetz (1967), this theory postulates that for-profit firms provide a high-power incentive mechanism through

\footnotetext{
4 However, in the majority of the Swiss cantons only public nursing homes and non-profit nursing homes receive subsidies from the government.

5 The data on for-profit nursing homes are not available to the authors.
} 
clearly defined property rights. As residual claimants of the enterprise, owners have both the financial incentive and the means to induce an efficient performance in the firm. ${ }^{6}$ The distinction between non-profit and public organizations is however more subtle. In principle, there is no significant difference in the property rights defined in public and non-profit organizations. These two orga nization types are similar in several aspects: First, the directors do not have any direct pecuniary gain from profits, but may have non-pecuniary benefits or perquisites. Secondly, in both types there are intrinsic motivations to work efficiently. These incentives may be driven by the organization's mission, organizational culture and trust, and long-term career paths. ${ }^{7}$ One may argue however, that such motivations are more pronounced and clear in private non-profit foundations, driven by the very mission of those foundations.

There are other theoretical arguments that public non-profit foundations have a more efficient performance than organizations operated directly by government administration. The first argument is derived from public choice theory. The basic idea of these models proposed by Niskanen $(1968,1971)$ is that the bureaucrats responsible for delivering a fixed amount of output with a budget, have a tendency to over-budget and to produce more bureaucratic output than is socially optimal. To reach this goal they have incentives to respond to the demands of the political process with its different distribution of power. For politicians the incentive is to shift costs and benefits so that the net benefits to their constituency are positive. This leads to a "political optimisation" which may conflict with cost efficiency. On the other hand, managers of non-profit nursing homes may likewise have no strong incentive to be efficient, since efficiency cannot be lawfully rewarded. However, the incentive for these managers to be efficient may result from their personal satisfaction in providing a particular social service, which is likely to be stronger than their counterparts in the public sector. ${ }^{8}$

Moreover, in the case of the Swiss nursing homes, the decision-making process of a non-profit foundation has more flexibility and not influenced by the politicians. In the case of a state-owned firm, the taxpayers are the owners of the firm and control the way the firm conducts its activities through their representatives in the parliament and in the government. These representatives are responsible for managing the company in order to maximize the social welfare. Public representatives in turn, delegate the authority to a commission which oversees the company's management. Compared to nonprofit firms, public firms experience an attenuation of property rights resulting in a more significant reduction in incentives for the

\footnotetext{
6 The owners can solve at least theoretically, the agency problems by sharing the risks with the managers.

7 See for instance DiIulio (1994) for the "principled" behavior of managers in public firms.

8 See Weisbrod (1997) for an interesting presentation of the efficiency incentives of nonprofit organizations.
} 
management to minimize costs and to follow the owner's interests. Moreover, the agency problems within state-owned companies are more complex than those in the private sector. In the case of a for-profit or nonprofit private firm, the management itself answers only to the owners, and the employment relationship involves the management and the employees. In the public sector, the chain of command from the electorate to the management goes through the parliament, the government and the government-appointed commission responsible for stateowned firms. Public firms involve many principalagent relationships, and agency problems can arise at each stage. In the face of such agency problems monitoring managers is more difficult and the efficient performance is harder to achieve. Therefore, compared to non-profit firms, the state-operated firms are more likely to be away from efficiency. Moreover, the boards of directors in state-owned firms are often political appointments and represent political parties whose objectives may not be cost minimization. Private nonprofit firms are clearly less politicized than state-owned firms. Finally, the nursing homes created by local governments in form of foundations are also generally less influenced by the political process and experience less principalagent relationships than the nursing homes included in the local administration.

In this paper we study the effect of ownership and institutional form on the production cost using a sample of Ticino's nursing homes. As discussed above, one can expect that nursing homes with different status are different regarding cost-efficiency. There are however, several problems that may complicate the empirical analysis: First, public and non-profit nursing homes may have different resident case-mixes thus different costs. Secondly, costminimization is constrained by a minimum quality of care. It is not clear that public and nonprofit nursing homes have the same attitude towards quality. It is therefore necessary to control for the differences in quality and case-mix.

\section{Methodology}

A stochastic cost frontier approach is adopted in this paper. A frontier cost function defines minimum costs given output level, input prices and the existing production technology. Due to technical and allocative inefficiencies it is unlikely that all firms operate at the frontier. The main advantage of the stochastic cost frontier approach compared to the deterministic approach is the separation of the inefficiency effect from the statistical noise.

The main approaches that can be used to estimate a frontier cost function with panel data are: Random effects model without inefficiency distribution restriction, Fixed effects 
model and Random effects model with a restriction on the distribution of the inefficiency. ${ }^{9}$ In this paper a random effects model with time-invariant inefficiency ${ }^{10}$ in line with the model proposed by Pitt and Lee (1981) and Schmidt and Sickles (1984) is considered. ${ }^{11} \mathrm{We}$ excluded the fixed effects model because the inefficiency indicators estimated by this approach may contain relatively high estimation errors due to the incidental parameters problem. Moreover, we did not use the third approach because it imposes a distribution on the inefficiency indicators. ${ }^{12}$

In order to study the effect of institutional type on cost efficiency, a two-stage method is used. In the first stage, the cost frontier is estimated and the nursing homes' inefficiency scores are calculated. In the second stage the estimated inefficiency score are analyzed with respect to the nursing home's type. Basically the sample is divided into two sub-samples: public and private non-profit nursing homes. The hypothesis that the inefficiency terms of the two sub-samples are from a single population is studied using Kruskal-Wallis test. ${ }^{13}$ Moreover, in a second step of this efficiency analysis we created two other sub-samples: nursing homes (public and private) operated by a foundation and public nursing homes integrated in the local administration. The advantage of the two-stage approach is that the effect of any time-invariant factor can be identified in the second stage. The analysis is performed with several specifications. This section provides a description of the cost frontier models and econometric specifications used in the paper.

\subsection{Specification of the Frontier Cost Function}

A nursing home can be represented as a firm transforming two inputs into patient-days of residential health and social care for elderly people. Moreover, in the cost model specification we take into account a number of output characteristic variables, which should capture, at least partially, the heterogeneity and quality dimension of the output of a nursing home. Assuming that output and input prices are exogenous, and that (for a given technology)

\footnotetext{
9 See Battese (1992), Kumbhakar and Lovell (2000) and Simar (1992) for general overviews of these methods. 10 Notice that since the institutional form in our sample does not change over time, there is no need to consider models with time-variant inefficiency.

11 Note however that unlike Pitt and Lee we do not assume any form of distribution on the random effects. See also Kumbhakar and Lovell (2000) for more details.

12 For a discussion on the advantages and disadvantages of different approaches see Kumbhakar and Lovell (2000).

13 See Singh and Coelli (2001) for an application of this test to compare the efficiency of Indian dairy plants in cooperative and private sectors.
} 
firms choose input levels to minimize costs, the firm's total cost of operating a nursing home can be represented by the following cost function:

$$
T C=f\left(Y, Q, R, P_{K}, P_{L}, \tau\right)
$$

where $T C$ represents total annual cost and $Y$ is the output represented by the total number of resident-days of the nursing home. $P_{K}$ and $P_{L}$ are respectively the prices of capital and labor. ${ }^{14} Q$ is the average dependency index calculated annually by the Regional Department of Public Health. This index measures the average required assistance of a given nursing home's patients with normal daily activities such as eating, personal care or performing physiological functions. $Q$ varies from 1 to 3 , with 3 representing the most severe (dependent) case. $R$ is the nursing staff ratio, that is the ratio of the number of employed nurses in a nursing home to the number of nurses that should be employed according to the guidelines of the Regional Department of Public Health. ${ }^{15}$ Since the nursing care is a labor-intensive service and the quality of care depends on the time spent by nurses for each patient, this variable represents the quality of output and the production process. ${ }^{16}$ Finally, $\tau$ is a linear time trend that captures the changes in technical efficiency associated with technical progress.

Since the residents are assigned to the nursing homes by the canton's authorities, variable $Q$ can be considered as an exogenous output characteristic. However, noting that this variable is obtained from a more or less subjective evaluation of the required caring time for each patient, one may as well argue that different nursing homes may have different evaluation or reporting criteria. Estimations would be biased should one type of nursing homes systematically over-report the dependency of their residents. To avoid any potential bias, we consider an alternative specification in which the dependency variable is excluded from the cost function.

It is generally assumed that the cost function given in (1) is the result of cost minimization given input prices and output and should therefore satisfy certain properties. ${ }^{17}$ Mainly, this function must be non-decreasing, concave, linearly homogeneous in input prices and non-decreasing in output. To estimate the cost function (1), a translog functional form is employed. This flexible functional form is a local, second-order approximation to any arbitrary cost function. It places no a priori restrictions on the elasticity of substitution and

\footnotetext{
14 For a similar cost model specification see Filippini (2001). However, Filippini (2001) uses a smaller data set (38 nursing homes over the period 1993-1995) and did not estimate a cost frontier model.

15 These guidelines are only recommendations and the nursing homes are not required to exactly follow them. 16 See Cohen and Spector (1996) and McKay (1988) for a similar approach when considering some measures of quality in a cost model for nursing homes. Cohen and Spector measured quality of care by case-mix adjusted staff to resident ratios. McKay used "nursing hours per patient" to measure the nursing home's quality.
} 
allows the economies of scale to vary with the output level. ${ }^{18}$ The translog approximation to (1) can be written as:

$$
\begin{aligned}
\ln \left(\frac{T C_{i t}}{P_{K_{i t}}}\right)= & \alpha_{0}+\alpha_{y} \ln Y_{i t}+\alpha_{Q} \ln Q_{i t}+\alpha_{R} \ln R_{i t}+\alpha_{L} \ln \frac{P_{L_{t t}}}{P_{K_{i t}}} \\
& +\frac{1}{2} \alpha_{y y}\left(\ln Y_{i t}\right)^{2}+\frac{1}{2} \alpha_{L L}\left(\ln \frac{P_{L_{i t}}}{P_{K_{i t}}}\right)^{2}+\frac{1}{2} \alpha_{Q Q}\left(\ln Q_{i t}\right)^{2}+\frac{1}{2} \alpha_{R R}\left(\ln R_{i t}\right)^{2} \\
& +\alpha_{y L} \ln Y_{i t} \ln \frac{P_{L_{i t}}}{P_{K_{i t}}}+\alpha_{y Q} \ln Y_{i t} \ln Q_{i t}+\alpha_{y R} \ln Y_{i t} \ln R_{i t}+\alpha_{Q R} \ln Q_{i t} \ln R_{i t} \\
& +\alpha_{L Q} \ln \frac{P_{L_{i t}}}{P_{K_{i t}}} \ln Q_{i t}+\alpha_{L R} \ln \frac{P_{L_{t i}}}{P_{K_{i t}}} \ln R_{i t}+\alpha_{\tau} \tau+u_{i}+v_{i t} \\
& \text { with } i=1,2, \ldots, N \text { and } t=1,2, \ldots, T
\end{aligned}
$$

where $u_{i}$ is a positive one-sided disturbance capturing the effect of inefficiency and $v_{i t}$ is a random error term $v_{i t}$. Note that by normalizing total costs and input prices by one of the input prices, we impose the theoretical condition of linear homogeneity in input prices. The other theoretical restrictions are verified after the estimation. In particular, the concavity of the estimated cost function reflects the fact that the cost function is a result of cost minimization. However, this assumption may be unrealistic for public and non-profit firms especially in sectors like health care, where other factors like quality may be as important as cost considerations. However, in the spirit of Bös (1986), we contend that although the functions based on cost optimization may not be consistent with the actual objectives of certain firms, they can still be used as a "behavioral" cost functions and can be helpful in studying the behavior of such firms. ${ }^{19}$

\section{Data}

The data set used in this paper is prepared based on the annual accounting reports of 36 nursing homes in canton Ticino over the 9-year period from 1993 to 2001. The sample includes more than two thirds of Ticino's nursing homes. The sample includes 14 private nonprofit homes, 5 public non-profit foundations and 17 public institutions. Ticino has a few forprofit nursing homes which are excluded from this study. All the nursing homes in the sample

17 For more details on the functional form of the cost function see Cornes (1992), p.106.

18 Translog functional form requires that the underlying cost function be approximated around a specific point. In our case this point is taken as the median of all variables. Therefore, all independent variables are normalized by their median. 
provide inpatient services. ${ }^{20}$ There are four missing observations in 1993, leaving a total of 320 observations. The variables include total costs, total number of employees (in terms of full-time equivalent units), average wage per employee per year, total number of beds and total number of resident-days. Other characteristics are ownership form (public/non-profit) of the nursing home, the number of external apartment beds maintained by the home and the number of caring personnel working for the nursing home.

Total cost is taken as the total annual expenditures of the nursing home. Output is measured in total number of patient-days of the nursing home. Average yearly wage rates are estimated as the weighted mean of the average wage rates of different professional categories working in a nursing home, including nurses, administrative and technical staff and physicians. Following Friedlaender and Wang Chiang (1983), Filippini and Maggi (1993), and Filippini (2001), the capital price is calculated from the residual costs divided by the capital stock. Residual cost is total cost minus labor cost. Similar to Wagstaff (1989), the capital stock is approximated by the number of beds operated by the nursing home. ${ }^{21}$ The quality indicators, $Q$ and $R$, (as described earlier) are calculated annually by the regional Department of Public Health. The summary statistics of some of the main variables used in the analysis are given in table 1. All money values are converted to 2000 Swiss Francs using the global consumer price index.

As it can be seen in the table, there is a high variation in the costs of a patient-day care. The input prices show a great amount of variation as well. Part of these variations is associated with time variation. For instance the average cost of a patient-day care has increased from about 154 Francs in 1993 to 214 Francs in 2001. In the same period, the price of labor has increased about 15 percent in real terms and our measure of real capital price has increased about 20 percent. However, the organizational type of the nursing homes has not changed in our sample.

Table 2 lists means and standard deviations of the main variables by organizational type. This table also reports the results of Kruskal-Wallis test and one sided t-test, that gives an indication of the statistical significance of the differences between public and non-profit nursing homes. The first observation on table 2 is that the non-profit nursing homes are on average more costly and smaller than the public ones. This result however, does not bear any

19 See Bös (1986), page 343.

20 There are some nursing homes that offer the possibility of nursing care in external residential apartments. The nursing care of this type is less intensive (thus less costly) than the care given to the home's residents. For this reason we excluded four nursing homes whose share of external beds is more than 10 percent of their total beds. 
conclusion on cost-efficiency. For instance, as it can be seen in the table, public homes have access to a relatively lower capital price. Public nursing homes may have access to more governmental subsidies for equipments and buildings. Moreover, the patients' case mix in non-profit nursing homes is on average more "dependent", thus more costly. Given that the patients are assigned to the nursing homes mainly based on proximity criteria, this finding may seem surprising.

\section{Table 1. Descriptive statistics (320 observations)}

\begin{tabular}{|c|c|c|c|c|c|}
\hline & Mean & $\begin{array}{l}\text { Standard } \\
\text { Deviation }\end{array}$ & Median & Minimum & Maximum \\
\hline $\begin{array}{l}\text { Total annual costs per } \\
\text { resident-day (SFr) }\end{array}$ & 184.05 & 28.92 & 183.10 & 111.85 & 279.81 \\
\hline $\begin{array}{l}\text { Total annual resident- } \\
\text { days }(Y)\end{array}$ & 23175.7 & 9684.4 & 21482 & 6525 & 58324 \\
\hline Number of beds & 66.23 & 26.81 & 61 & 28 & 162 \\
\hline $\begin{array}{l}\text { Average labor price } \\
\left(P_{L}\right) \text { in } \mathrm{SFr} \text { per } \\
\text { employee per year }\end{array}$ & 70157.4 & 6586.4 & 70280.1 & 29744.3 & 122950.2 \\
\hline $\begin{array}{l}\text { Average capital price } \\
\left(P_{K}\right) \text { in SFr per bed }\end{array}$ & 11008.3 & 2579.1 & 10714.1 & 3465.8 & 22426.3 \\
\hline $\begin{array}{l}\text { Average dependency } \\
\text { index }(Q)\end{array}$ & 2.575 & .219 & 2.6 & 1.87 & 3 \\
\hline Nursing staff ratio $(R)$ & .963 & .124 & .97 & .49 & 1.55 \\
\hline Non-Profit $(N P)$ & .531 & .500 & 1 & 0 & 1 \\
\hline
\end{tabular}

- All monetary values are in 2000 Swiss Francs (CHF), adjusted for inflation by Switzerland's global consumer price index.

A more careful look at the differences shows that on average, the non-profit foundations aeated by municipalities have the most dependent cases and public nursing homes have the least dependent case-mix. These differences may be related to demographic variations and health status of different locations in the canton. However, such a contrasting difference may also be at least partly, due to the variations in reporting dependency index by nursing homes to canton's authorities. If a group of nursing homes systematically over-report

21 A more precise estimation of capital stock would require capital inventory data, which are not available to us. 
the severity of their case-mix, this may create a bias in the estimation of cost-efficiency. In order to identify the extent of such potential biases, an additional specification without control for severity is used. Comparing the results between the model with and without severity can help determine the direction of this bias.

Table 2. Means of the main variables by organizational type

\begin{tabular}{|c|c|c|c|c|c|}
\hline & \multicolumn{3}{|c|}{$\begin{array}{c}\text { Mean } \\
\text { (Standard Deviation) }\end{array}$} & \multicolumn{2}{|c|}{$\begin{array}{c}\text { P-value } \\
\text { One-sided t-test }\end{array}$} \\
\hline & $\begin{array}{c}\text { Private } \\
\text { Foundations }\end{array}$ & $\begin{array}{c}\text { Public } \\
\text { Foundations }\end{array}$ & $\begin{array}{c}\text { Public } \\
\text { Administration }\end{array}$ & $\begin{array}{l}\text { Public vs } \\
\text { Private }\end{array}$ & $\begin{array}{c}\text { Foundations vs } \\
\text { Public } \\
\text { Administration } \\
\end{array}$ \\
\hline $\begin{array}{ll}\text { Total annual costs } \\
\text { per resident-day } \\
\text { (SFr) }\end{array}$ & $\begin{array}{l}187.0 \\
(33.6)\end{array}$ & $\begin{array}{l}186.5 \\
(31.0)\end{array}$ & $\begin{array}{l}180.9 \\
(23.3)\end{array}$ & .075 & $0.033 *$ \\
\hline $\begin{array}{l}\text { Total annual } \\
\text { resident-days }(Y)\end{array}$ & $\begin{array}{l}19,592 \\
(7,802)\end{array}$ & $\begin{array}{l}18,640 \\
(5,544)\end{array}$ & $\begin{array}{c}27,523 \\
(10,249)\end{array}$ & $.0000 * *$ & $0.0000 * *$ \\
\hline Number of beds & $\begin{array}{l}55.8 \\
(22.2)\end{array}$ & $\begin{array}{c}55.4 \\
(17.7)\end{array}$ & $\begin{array}{c}78.2 \\
(27.7)\end{array}$ & $.0000 * *$ & $0.0000 * *$ \\
\hline $\begin{array}{l}\text { Average labor } \\
\text { price }\left(P_{L}\right) \text { in } \mathrm{SFr} \\
\text { per employee per } \\
\text { year }\end{array}$ & $\begin{array}{l}69,168 \\
(8585)\end{array}$ & $\begin{array}{l}71,275 \\
(5,955)\end{array}$ & $\begin{array}{l}70,647 \\
(4,430)\end{array}$ & $.016 *$ & 0.106 \\
\hline $\begin{array}{l}\text { Average capital } \\
\text { price }\left(P_{K}\right) \text { in SFr } \\
\text { per bed }\end{array}$ & $\begin{array}{l}12,718 \\
(2,593)\end{array}$ & $\begin{array}{l}10,180 \\
(1,918)\end{array}$ & $\begin{array}{c}9,832 \\
(1,873)\end{array}$ & $.0000 * *$ & $.0000 * *$ \\
\hline $\begin{array}{l}\text { Average } \\
\text { dependency index } \\
(Q)\end{array}$ & $\begin{array}{l}2.58 \\
(.21)\end{array}$ & $\begin{array}{l}2.65 \\
(.25)\end{array}$ & $\begin{array}{l}2.54 \\
(.21)\end{array}$ & .27 & $0.008 * *$ \\
\hline $\begin{array}{l}\text { Nursing staff ratio } \\
(R)\end{array}$ & $\begin{array}{l}.963 \\
(.144)\end{array}$ & $\begin{array}{l}.927 \\
(.129)\end{array}$ & $\begin{array}{l}.975 \\
(.101)\end{array}$ & .48 & 0.062 \\
\hline $\begin{array}{l}\text { Share of total } \\
\text { resident-days }(\%) \\
\text { Share of beds }(\%) \\
\text { \# of observations } \\
\text { \# of homes }\end{array}$ & $\begin{array}{c}33.0 \\
32.9 \\
125 \\
14\end{array}$ & $\begin{array}{c}11.3 \\
11.8 \\
45 \\
5\end{array}$ & $\begin{array}{c}55.7 \\
55.3 \\
150 \\
17\end{array}$ & & \\
\hline
\end{tabular}

- Standard deviations are given in brackets.

- * means that the difference (between public and non-profit groups) is significant at lower than 5\% significance level. $* *$ means the significance level is less than $1 \%$.

- All monetary values are in 2000 Swiss Francs (CHF), adjusted for inflation by Switzerland's global consumer price index. 


\section{Estimation results}

The estimated parameters of the cost frontier are listed in table 3. Model $I$ is according to equation 2 . In model $I I$ the average dependency index $(Q)$ is excluded from the explanatory variables. This specification is used to study the extent to which the differences between two types of nursing homes are due to their different resident case-mixes.

\section{Table 3. Estimated coefficients}

\begin{tabular}{|c|c|c|}
\hline & Model I & Model II \\
\hline$\alpha_{y}$ & $\begin{array}{c}.890 \\
(.017)\end{array}$ & $\begin{array}{c}.822 \\
(.021)\end{array}$ \\
\hline$\alpha_{Q}$ & $\begin{array}{c}.555 \\
(.083)\end{array}$ & - \\
\hline$\alpha_{R}$ & $\begin{array}{l}.382 \\
(.046)\end{array}$ & $\begin{array}{l}.256 \\
(.045)\end{array}$ \\
\hline$\alpha_{L}$ & $\begin{array}{c}.832 \\
(.025)\end{array}$ & $\begin{array}{l}.816 \\
(.026)\end{array}$ \\
\hline$\alpha_{y y}$ & $\begin{array}{l}-.024 \\
(.053)\end{array}$ & $\begin{array}{l}-.112 \\
(.059)\end{array}$ \\
\hline$\alpha_{Q Q}$ & $\begin{array}{l}-.558 \\
(.900)\end{array}$ & - \\
\hline$\alpha_{L L}$ & $\begin{array}{c}.612 \\
(.075)\end{array}$ & $\begin{array}{l}.576 \\
(.078)\end{array}$ \\
\hline$\alpha_{y Q}$ & $\begin{array}{l}-.011 \\
(.12)\end{array}$ & - \\
\hline$\alpha_{y L}$ & $\begin{array}{c}-.00006 \\
(.042)\end{array}$ & $\begin{array}{l}-.016 \\
(.042)\end{array}$ \\
\hline$\alpha_{L Q}$ & $\begin{array}{l}.034 \\
(.17)\end{array}$ & - \\
\hline$\alpha_{R R}$ & $\begin{array}{l}-.113 \\
(.214)\end{array}$ & $\begin{array}{l}-.276 \\
(.216)\end{array}$ \\
\hline$\alpha_{y R}$ & $\begin{array}{c}.223 \\
(.098)\end{array}$ & $\begin{array}{c}.296 \\
(.099)\end{array}$ \\
\hline$\alpha_{L R}$ & $\begin{array}{l}.348 \\
(.12)\end{array}$ & $\begin{array}{l}.325 \\
(.121)\end{array}$ \\
\hline$\alpha_{Q R}$ & $\begin{array}{l}-.587 \\
(.34)\end{array}$ & - \\
\hline$\alpha_{\tau}$ & $\begin{array}{c}.012 \\
(.0022)\end{array}$ & $\begin{array}{c}.024 \\
(.0017)\end{array}$ \\
\hline Constant & $\begin{array}{l}15.15 \\
(.013)\end{array}$ & $\begin{array}{l}15.10 \\
(.014)\end{array}$ \\
\hline R-square & .9754 & .9607 \\
\hline
\end{tabular}

Standard errors are given in brackets.

- The sample includes 320 observations (36 nursing homes) 
The regression results show that all the first-order terms are significant and in a reasonable direction. As expected, output and prices have a positive effect on costs, and the nursing homes with a more severe case-mix and/or with a higher quality of service are relatively more costly. ${ }^{22}$ Since total cost and the regressors are in logarithms and have been normalized, the first order coefficients are interpretable as cost elasticities evaluated at the sample median. The output elasticity is positive and implies that an increase in the supply will increase total cost. A $1 \%$ increase in the number of patient-days of nursing home care will increase the total cost by approximately $0.9 \%$ (Model $I$ ), $0.8 \%$ (Model II), respectively.

The cost elasticities with respect to the output characteristics variables, $Q$ and $R$, are positive and imply that an increase in the average required assistance of a home's patients or an increase in the ratio of the number of nurses employed by a nursing home and the number of nurses that should theoretically be employed will increase total cost.

The coefficient of the linear trend suggests that the total costs have increased over time with a rate of about 1 to 2 percent per year. The growth of costs is a commonly observed phenomenon in labor-intensive industries such as health care, which usually face a persistent growth of labor price. The estimated cost functions do not however satisfy the concavity condition in input prices. ${ }^{23}$ This may suggest that the estimated cost functions are not resulted from a complete cost-minimization strategy. Therefore, these results should be interpreted in the behavioral cost framework proposed by Bös (1986).

\section{Cost-efficiency, ownership and institutional form}

Table 4 provides a summary of the estimated inefficiency measures for three groups of nursing homes. The inefficiency score is defined as $\exp \left(u_{i}\right)$, where $u_{i}$ is the inefficiency term obtained from the regression model. These measures represent the ratio of a nursing home's actual costs to a minimum level that would have been achieved had the firm operated as costefficient as the "best practice" observed in the sample. Comparing the two specifications, with and without average dependency index, indicates that part of the difference between different nursing homes is related to the residents case-mix. When the dependency is not taken into account, model II predicts that the non-profit homes are on average 7 percent more costefficient (second column). However, when the differences in case-mix are controlled for, this difference reduces to about 3 percent (first column).

22 These findings are in line with the results obtained by Filippini (2001). 
As expected, the inefficiency estimates obtained from model II are higher than those of model $I$. The exclusion of variable $Q$ from the model specification increases the value of the composed error terms and also the inefficiency term. The inefficiency scores obtained from model II can therefore be overestimated. The results obtained from model $I$ show relatively low values of inefficiency indicators. This means that the nursing homes included in our sample are comparatively efficient.

\section{Table 4. Inefficiency measures:}

\begin{tabular}{|c|c|c|c|}
\hline & & Model I & Model II \\
\hline \multirow{5}{*}{ 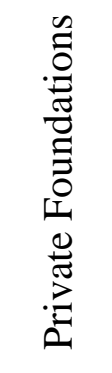 } & Mean & 1.07 & 1.21 \\
\hline & St. Deviation & .038 & .089 \\
\hline & $1^{\text {st }}$ quartile & 1.05 & 1.19 \\
\hline & Median & 1.07 & 1.23 \\
\hline & $3^{\text {rd }}$ quartile & 1.09 & 1.26 \\
\hline \multirow{5}{*}{ 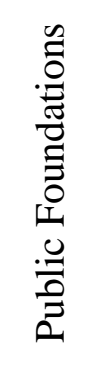 } & Mean & 1.08 & 1.23 \\
\hline & St. Deviation & .054 & .13 \\
\hline & $1^{\text {st }}$ quartile & 1.10 & 1.23 \\
\hline & Median & 1.10 & 1.28 \\
\hline & $3^{\text {rd }}$ quartile & 1.13 & 1.30 \\
\hline \multirow{5}{*}{ 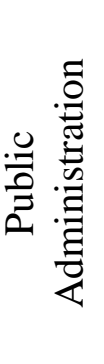 } & Mean & 1.10 & 1.28 \\
\hline & St. Deviation & .028 & .057 \\
\hline & $1^{\text {st }}$ quartile & 1.03 & 1.13 \\
\hline & Median & 1.08 & 1.15 \\
\hline & $3^{\text {rd }}$ quartile & 1.12 & 1.36 \\
\hline
\end{tabular}

- Inefficiency measures represent the ratio of a nursing home's actual costs to minimum costs from the best practice in the sample.

The results of Kruskal-Wallis test on the differences in inefficiency scores between different groups are given in table 5. The results are in general robust to specification in the sense that the comparative cost-efficiency of different types of nursing homes does not

23 Our results indicate that the Hessian matrix of the estimated cost function with respect to input prices (labor and capital) is not negative semi-definite, thus the concavity condition is not satisfied in any of the 
depend on their reported case-mix severity. These results suggest that private nursing homes are on average, slightly more cost-efficient than the homes owned by governments. Moreover, the foundations, regardless of whether they are owned by public or private sector, are slightly more cost-efficient than the nursing homes integrated in the local public administration. ${ }^{24}$ Foundations, perhaps due to a relatively low influence of the political and bureaucratic process on the management, seem to be an interesting institutional form even for public nursing homes. The Kruskal-Wallis tests results (not shown here) do not indicate any significant difference between public foundations and private non-profit nursing homes. However, because of the relatively low number of public foundations in our sample, this result may be due to estimation errors.

Table 5. Kruskal-Wallis test results:

\begin{tabular}{ccc|ccc}
\hline & & $\begin{array}{c}\text { P-value } \\
\text { Model } I\end{array}$ & $\begin{array}{c}\text { P-value } \\
\text { Model } I I\end{array}$ & $\begin{array}{c}\text { More efficient } \\
\text { group }\end{array}$ \\
\hline Public & vs & Private & .021 & .056 & Private Homes \\
\hline Foundations & vs & $\begin{array}{c}\text { Public } \\
\text { Administration }\end{array}$ & .011 & .032 & Foundations \\
\hline
\end{tabular}

\section{Scale economies}

Scale efficiency ndicates the degree to which a company is producing at optimal scale. Frisch (1965) defines the optimal scale as the level of operation where the scale elasticity is equal to one. Returns to scale $(R S)$ is defined as the proportional increase in total cost resulting from a proportional increase in output (Y), holding all input prices and output characteristic variables fixed. This is equivalent to the inverse of the elasticity of total cost with respect to the output (Caves, Christensen, and Tretheway 1984). The returns to scale can therefore be obtained from:

$$
R S=1 /\left(\frac{\partial \ln T C}{\partial \ln Y}\right)
$$

specifications.

24 This result is consistent with the findings reported in Crivelli and Filippini (2002) who used a different sample of Ticino's nursing homes and a different methodology. 
There are increasing returns to scale if $R S$ is greater than 1, and conversely, there are decreasing returns to scale if $R S$ is below 1 . In the case of $R S=1$ we have a constant returns to scale situation. Economies of scale exist if the average costs of a nursing home decrease as output increases. Table 5 shows the values of $R S$ calculated for representative nursing homes of our sample. ${ }^{25}$ The results are given only for the main specification with control for dependency index (model $I){ }^{26}$

Table 6. Returns to scale $(R S)$ :

\begin{tabular}{lccc}
\hline $\begin{array}{l}\text { Representative } \\
\text { Nursing Home }\end{array}$ & $\begin{array}{c}\text { Size (Number } \\
\text { of Beds) }\end{array}$ & $\begin{array}{c}\text { Resident-days per } \\
\text { Year }\end{array}$ & $\begin{array}{c}\text { Returns to scale } \\
(R S)\end{array}$ \\
\hline $1^{\text {st }}$ Quartile & 47 & 15,740 & 1.134 \\
& & & $(.030)$ \\
Median & 61 & 21,480 & 1.124 \\
& & & $(.021)$ \\
$3^{\text {rd }}$ Quartile & 80 & 28,790 & 1.116 \\
& & & $(.029)$ \\
Maximum & 162 & 58,320 & 1.032 \\
& & & $(.060)$ \\
\hline
\end{tabular}

- Standard errors are given in brackets.

- Only specification $I$ is considered.

The estimated values of returns to scale range from a minimum of about 1 for the largest nursing home to a maximum of 1.3 for the smallest one. The results suggest that a great majority of the nursing homes in our sample do not fully exploit the scale economies. This is an important policy implication that is worth considering especially, in the organization of some of these nursing homes that operate in the same area, but are operated by different municipalities.

\section{Discussion and conclusions}

This paper considers the estimation of a translog cost function for a sample of 36 Swiss nursing homes in canton Ticino using panel data for a mine-year period from 1993 to 2001. A random effects stochastic frontier model is considered. The results of this analysis

25 Equation (3) has been evaluated at the corresponding input prices and output characteristics variables, $Q$ and $R$. For instance the median of all variables is used to estimate the returns to scale for the "median" nursing home. 26 The results obtained from the alternative specification $I I$ are in general very close to the reported results. 
suggest that government nursing homes have slightly higher costs than non-profit nursing homes when other factors are taken into consideration. The results also suggest that in terms of efficiency, the non-profit foundations created by municipalities are rather similar to private non-profit nursing homes than the nursing homes operated by public administration. This finding is robust to the model specification. The sources of these cost differences are not clear. The results suggest however that the foundations created by local governments can be almost as efficient as private non-profit nursing homes. The relatively low efficiency of the nursing homes integrated in the public administration can therefore be explained by their strong bureaucratic constraints. However, we have to point out that these cost differences are limited to a few percentage points.

Finally, this paper provides empirical evidence for the presence of economies of scale at most output levels in Ticino's nursing homes. The results suggest that efficiency gains can be obtained from merging smaller nursing homes operating in the same area. Theoretically, economies of scale may also be obtained through partial mergers. For instance in many cases, savings may be obtained through joint purchase of food and medical supplies or by sharing some clinical and administrative functions. Nursing homes may also be able to reduce capital costs thanks to the ability of large businesses to negotiate lower interest rates. Further, the empirical results indicate that the economies of scale should be taken into account for planning the size of new nursing homes. However, it should be noted that because of relatively limited opportunities for human contacts, the quality of service can be low in excessively large nursing homes. This is an important factor that must be considered in the evaluation of a merger strategy.

\section{References}

Alchian, A. A. (1965), "Some economics of property rights", Il Politico, 30 (4): 816-829.

Battese, G. E. (1992) "Frontier Production Functions and Technical Efficiency: A Survey of Empirical Applications in Agricultural Economics", Agricultural Economics, 7, 185-208.

Bös, D. (1986) Public Enterprise Economics, Amsterdam, North-Holland.

Bradford, W.D. and L.R. Mobley (1997), "Behavioural differences among hospitals: It is ownership or location?", Applied economics, 29, 1125-1138.

Caves, W.C., L.R. Christensen and M.W. Tretheway (1984), "Economies of Density versus Economies of scale: Why trunk and Local Service Airlaine Costs Differ", Rand Journal of Economics, 15, 471-489.

Cohen, J. and W.D Spector (1996), "The effect of Medicaid Reimbursement on Quality of Care in Nursing Homes", Journal of Health Economics, 15, 23-48. 
Cornes, R. (1992), Duality and Modern Economics, Cambridge University Press.

Crivelli, L., M. Filippini and D. Lunati (2002) "Regulation, ownership and efficiency in the Swiss nursing home industry", International Journal of Health Care Finance and Economics, 2 (2): 79-97.

Crivelli, L. and M. Filippini (2002), "Institutional organisation and cost performance:

Evidence from the nursing home industry", in: Plural Economy and Socio-economic Regulation, Enjolras B. and M-L. von Bergmann-Winberg (eds), Napoli: 24th International Congress of CIRIEC, 165-176.

Demsetz, H. (1967) "Towards a theory of property rights", American Economic Review, Papers and Proceedings, 57: 346-359.

DiIolio, Jr. John D. (1994), "Principled agents: the cultural bases of behavior in a federal government bureaucracy", Journal of Public Administration Research and Theory, 3: 277 318.

Filippini, M. (2001) "Economies of scale in the Swiss nursing home industry", Applied Economics Letters, 8: 43-46.

Filippini, M. and R. Maggi (1993), "Efficiency and Regulation in the Case of the Swiss Private Railways", Journal of Regulatory Economics, 5, 199-216.

Friedlaender, A.F. and S.J.Wang Chiang (1983), "Productivity Growth in the Regulated Trucking Industry", Research in Transportation and Economics, 1, 149-184.

Frisch, R. (1965) Theory of Production, Dordrecht, 1965.

Kumbhakar, Subal C. and C. A. Knox Lovell (2000) Stochastic Frontier Analysis, Cambridge University Press, Cambridge.

McKay, N.L. (1988), "An Econometric Analysis of Costs and Scale Economies in the Nursing Home Industry", Journal of Human Resources, 23, 57-75.

Niskanen W.A. (1971), Bureacracy and Representative Government, Chicago, Aldine Atherton.

Niskanen W.A. (1968), 'The Peculiar Economics of Bureaucracy', American Economic Review, 42, 239-305.

Pitt, M. and L. Lee (1981) "The measurement and sources of technical inefficiency in Indonesian weaving industry", Journal of Development Economics, 9: 43-64.

Schmidt, P. and R.E. Sickles, (1984), Production Frontiers and Panel Data, Journal of Business and Economic Statistics, 2, 367-374.

Simar, L., (1992), 'Estimating Efficiencies from Frontier Models with Panel Data: A Comparison of Parametric, Non-parametric and Semi-parametric Methods with Bootstapping', The Journal of Productivity Analysis, 3, 171-203. 
Singh, Satbir and Tim Coelli (2001) "Performance of dairy plants in the cooperative and private sectors in India", Annals of Public and Cooperative Economics, 72 (4): 453-479.

Vitaliano, D.F. and M. Toren (1994), "Cost and efficiency in nursing homes: a stochastic frontier approach", Journal of Health economics, 13 , 281-300.

Wagstaff, A. (1989), "Estimating Efficiency in the Hospital Sector: a Comparison of Three Statistical Cost Frontier Models", Applied Economics, 21, 659-672.

Weisbrod B.A., (1997) 'The Future of the Nonprofit Sector: its Entwining with private Enterprise and Government', Journal of Policy Analysis and Management, 16, pp. 541555. 


\title{
QUADERNIDELLA FACOLTÀ
}

\author{
I quaderni sono richiedibili (nell'edizione a stampa) alla Biblioteca universitaria di Lugano \\ via G. Buffi 13 CH 6900 Lugano \\ e-mail: biblioteca@lu.unisi.ch
}

The working papers (printed version) may be obtained by contacting the Biblioteca universitaria di Lugano via G. Buffi 13 CH 6900 Lugano

e-mail: biblioteca@lu.unisi.ch

Quaderno n. 98-01

P. Balestra, Efficient (and parsimonious) estimation of structural dynamic error component models

Quaderno n. 99-01

M. Filippini, Cost and scale efficiency in the nursing home sector : evidence from Switzerland

Quaderno n. 99-02

L. Bernardi, I sistemi tributari di oggi : da dove vengono e dove vanno

Quaderno n. 99-03

L.L. Pasinetti, Economic theory and technical progress

Quaderno n. 99-04

G. Barone -Adesi, K. Giannopoulos, L. Vosper, VaR without correlations for portfolios of derivative securities

Quaderno n. 99-05

G. Barone-Adesi, Y. Kim, Incomplete information and the closed-end fund discount

Quaderno n. 99-06

G. Barone -Adesi, W. Allegretto, E. Dinenis, G. Sorwar, Valuation of derivatives based on CKLS interest rate models

Quaderno n. 99-07

M. Filippini, R. Maggi, J. Mägerle, Skalenerträge und optimale Betriebsgrösse bei den schweizerische Privatbahnen

Quaderno n. 99-08

E. Ronchetti, F. Trojani, Robust inference with GMM estimators

Quaderno n. 99-09

G.P. Torricelli, I cambiamenti strutturali dello sviluppo urbano e regionale in Svizzera e nel Ticino sulla base dei dati dei censimenti federali delle aziende 1985, 1991 e 1995 
Quaderno n. 00-01

E. Barone, G. Barone-Adesi, R. Masera, Requisiti patrimoniali, adeguatezza del capitale e gestione del rischio

Quaderno n. 00-02

G. Barone-Adesi, Does volatility pay?

Quaderno n. 00-03

G. Barone-Adesi, Y. Kim, Incomplete information and the closed-end fund discount

Quaderno n. 00-04

R. Ineichen, Dadi, astragali e gli inizi del calcolo delle probabilità

Quaderno n. 00-05

W. Allegretto, G. Barone-Adesi, E. Dinenis, Y. Lin, G. Sorwar, A new approach to check the free boundary of single factor interest rate put option

Quaderno n. 00-06

G.D.Marangoni, The Leontief Model and Economic Theory

Quaderno n. 00-07

B. Antonioli, R, Fazioli, M. Filippini, Il servizio di igiene urbana italiano tra concorrenza e monopolio

Quaderno n. 00-08

L. Crivelli, M. Filippini, D. Lunati. Dimensione ottima degli ospedali in uno Stato federale

Quaderno n. 00-09

L. Buchli, M. Filippini, Estimating the benefits of low flow alleviation in rivers: the case of the Ticino River

Quaderno n. 00-10

L. Bernardi, Fiscalità pubblica centralizzata e federale: aspetti generali e il caso italiano attuale

Quaderno n. 00-11

M. Alderighi, R. Maggi, Adoption and use of new information technology

Quaderno n. 00-12

F. Rossera, The use of log-linear models in transport economics: the problem of commuters' choice of mode

Quaderno n. 01-01

M. Filippini, P. Prioni, The influence of ownership on the cost of bus service provision in Switzerland. An empirical illustration

Quaderno n. 01-02

B. Antonioli, M. Filippini, Optimal size in the waste collection sector

Quaderno n. 01-03

B. Schmitt, La double charge du service de la dette extérieure 
Quaderno n. 01-04

L. Crivelli, M. Filippini, D. Lunati, Regulation, ownership and efficiency in the Swiss nursing home industry

Quaderno n. 01-05

S. Banfi, L. Buchli, M. Filippini, Il valore ricreativo del fiume Ticino per i pescatori

Quaderno n. 01-06

L. Crivelli, M. Filippini, D. Lunati, Effizienz der Pflegeheime in der Schweiz

Quaderno n. 02-01

B. Antonioli, M. Filippini, The use of a variable cost function in the regulation of the Italian water industry

Quaderno n. 02-02

B. Antonioli, S. Banfi, M. Filippini, La deregolamentazione del mercato elettrico svizzero e implicazioni a breve termine per l'industria idroelettrica

Quaderno n. 02-03

M. Filippini, J. Wild, M. Kuenzle, Using stochastic frontier analysis for the access price regulation of electricity networks

Quaderno n. 02-04

G. Cassese, On the structure of finitely additive martingales

Quaderno n. 03-01

M. Filippini, M. Kuenzle, Analisi dell'efficienza di costo delle compagnie di bus italiane e svizzere

Quaderno n. 03-02

C. Cambini, M. Filippini, Competitive tendering and optimal size in the regional bus transportation industry

Quaderno n. 03-03

L. Crivelli, M. Filippini, Federalismo e sistema sanitario svizzero

Quaderno n. 03-04

L. Crivelli, M. Filippini, I. Mosca, Federalismo e spesa sanitaria regionale : analisi empirica per i Cantoni svizzeri

Quaderno n. 03-05

M. Farsi, M. Filippini, Regulation and measuring cost efficiency with panel data models : application to electricity distribution utilities

Quaderno n. 03-06

M. Farsi, M. Filippini, An empirical analysis of cost efficiency in non-profit and public nursing homes 